\title{
Dendritic cells provide a potential link between smoking and inflammation in rheumatoid arthritis
}

\author{
Marina G Kazantseva', John Highton², Lisa K Stamp ${ }^{3}$ and Paul A Hessian ${ }^{1 *}$
}

\begin{abstract}
Introduction: Smoking increases the risk of developing rheumatoid arthritis (RA) and affects the severity of established RA. Smoking can impact on Th17 lymphocyte differentiation and function through activation of the aryl hydrocarbon receptor (AHR), a process with implications for the pathogenic mechanisms in RA that involve the cytokine, interleukin (IL)-17A. The objective of this study was to establish any effect of smoking on the inflammatory tissue lesions of rheumatoid arthritis via the AHR and IL-17A.

Methods: Twenty synovial and eighteen subcutaneous nodule tissue samples from 31 patients with RA were studied. Patient smoking status at the time of tissue collection was established. Expression of AHR, CYP1A1, AHRR, IL6, IL17A, IL17F, IL22, IL23, IL23R, IFNG, TBX21, IDO1 and FOXP3 genes were assessed in tissues and cultured cells using real-time PCR. Two-colour immunofluorescence was used to co-localise AHR and CYP1A1 protein in synovial tissues. The response of monocytes and monocyte-derived dendritic cells (mo-DCs) to the AHR agonist, benzo(a) pyrene (BaP) was compared in vitro.
\end{abstract}

Results: AHR gene expression was demonstrated in rheumatoid synovial tissues and nodules with significantly greater expression in synovia. Expression was not influenced by smoking in either tissue. Evidence of AHR activation, indicated by CYPIA1 and AHRR gene expression, was found only in synovia from patients who smoked. However, IL17A gene expression was lower in synovia from smokers. TBX21 and FOXP3 expression was not affected by smoking. Within the synovial tissues of smokers the principal cell type with evidence of AHR activation was a subset of synovial DCs. This observation was consistent with the sensitivity of human mo-DCs to BaP stimulation demonstrated in vitro. Exposure to BaP affected mo-DC function as demonstrated by decreased IL6 expression induced by Polyl:C, without affecting indoleamine 2,3 dioxygenase (IDO)1 expression.

Conclusion: Our findings show that one effect of smoking on inflamed rheumatoid synovial tissue involves activation of the AHR pathway. A subset of synovial DCs is important in the response to cigarette smoke. The potential for smoking to affect DC behaviour in joint tissues has relevance to both early and late phases of RA pathogenesis and warrants further investigation.

\section{Introduction}

Rheumatoid arthritis (RA) is a systemic autoimmune disease predominantly manifest as polyarthritis but with extra-articular complications such as rheumatoid nodules (granulomas) in more severe cases. Clinical evidence points to an effect of smoking on the severity of established RA. Patients with RA who continue to smoke cigarettes have higher disease activity and develop worse disability $[1,2]$. They have a greater requirement for

\footnotetext{
* Correspondence: paul.hessian@otago.ac.nz

'Department of Physiology, University of Otago, P.O. Box 913, Dunedin 9054, NZ
}

Full list of author information is available at the end of the article treatment with disease-modifying antirheumatic drugs (DMARDs) [3] and respond less well to anti-TNF agents $[4,5]$. Smokers with RA are also less likely to achieve sustained DMARD-free remission than non-smokers [6].

Interactions between genetic pre-disposition and environmental factors have been identified as important in determining the risk of developing RA. Approximately $50 \%$ of the risk is attributable to genetic factors with HLA-DRB1 shared epitope (SE) alleles the major genetic determinants of RA susceptibility $[7,8]$ and severity $[9,10]$. Other genetic risk loci particularly associated with the development of anti-citrullinated peptide antibody (ACPA)-positive RA, include genes that influence $\mathrm{T}$ cell

\section{Biomed Central}


function and the handling of arthritogenic antigens [11-13].

Epidemiologic data has established cigarette smoking as an important environmental factor that interacts powerfully with the SE to increase the risk for development of RA [14-16]. Smoking is associated with increased production of autoantibodies, including ACPA and rheumatoid factor (RF) and with increased incidence of extra-articular manifestations in RA that include the development of rheumatoid nodules [16,17]. Biologic mechanisms that explain the epidemiologic data and accommodate an influence of the SE are increasingly understood $[15,18,19]$. One aspect is that smoking enhances the expression of peptidylarginine deiminase and consequently increases the generation of citrullinated protein(s) within the lung alveolar compartment [20]. There is evidence that antibodies reacting with citrullinated whole proteins, contribute to the pathogenesis of RA. These include antibodies to citrullinated fibrinogen or collagen type II that are involved in immune-complex mediated inflammation as well as antibodies to citrullinated $\alpha$-enolase, which are particularly associated with $\mathrm{SE}^{+} H L A-D R B 1$ alleles and that identify patients with a higher frequency of joint erosions and RF positivity [21-23]. Furthermore, T cells in RA patients also respond to citrullinated aggrecan peptides [24]. Thus, smoking and interactions between smoking and genetic variants contribute to autoimmunity against post-translationally modified (citrullinated) peptides/proteins that are important in the pathogenesis of RA [25].

Of further relevance is the potential for smoking to influence $\mathrm{T}$ helper (Th)17 lymphocyte-mediated inflammation. Polycyclic aromatic hydrocarbons (PAHs) are amongst a number of compounds present in cigarette smoke that activate the aryl hydrocarbon receptor (AHR), a transcription factor that binds to xenobiotic response elements (XRE) and regulates gene expression. Genes encoding select members of the cytochrome P450 (CYP) family of enzymes, (for example, CYP1A1), and the AHR repressor $(A H R R)$ are particularly responsive to liganddependent AHR activation, a characteristic used to distinguish AHR activation. In vitro evidence shows that the activation of AHR also promotes the differentiation of Th17 lymphocytes and consequently the production of the Th17-related cytokines, interleukin (IL)-17A, IL-17F and IL-22 [26]. Experimental models of arthritis and clinical indications have highlighted an important role for IL-17A in the pathogenesis of RA [27-29]. Thus the AHR provides another potential link between exposure to compounds in cigarette smoke and the notable effect that smoking has on rheumatoid inflammation. To address this possibility, we set out to establish the presence of the AHR in the tissues of patients with RA, to seek evidence for activation of the AHR pathway in joint and extra-articular sites of inflammation in smokers and non-smokers, and to investigate corresponding levels of IL17A expression. Our results indicate AHR activation in synovial tissue, associated with smoking. Synovial dendritic cells are sensitive to AHR ligand and in RA patients respond with activation of the AHR. Contrary to expectation the activation of AHR in synovial tissue was not associated with increased IL-17A expression.

\section{Materials and methods}

\section{Patients and tissue samples}

Twenty synovial and eighteen nodule tissue samples were obtained from 31 patients with RA. All patients fulfilled American Rheumatism Association 1987 classification criteria for RA [30]. Patients were classified according to their reported smoking habits as either: (i) smokers (actively smoking when the tissue sample was taken) - including those who were daily or non-daily smokers of tobacco via cigarettes or loose tobacco; or (ii) non-smokers - including ex-smokers (those who ceased smoking $\geq 3$ months prior to nodule samples or $\geq 8$ years prior to synovial samples being taken), and those who have never smoked tobacco in their lifetime. The demographics of RA patients contributing synovial and/or nodule tissue are summarised in Table 1. With two exceptions, all RA patients included in this study were $\mathrm{SE}^{+}$(overall single copy of $\mathrm{SE}, \mathrm{n}=20(65 \%)$; double copy of SE, $n=9(29 \%)$ ).

Two synovial samples were available from three patients (one smoker, two non-smokers), taken 6 months, 1 year and 5 years apart respectively. Paired synovial and nodule samples were obtained at the same time from four separate patients (one smoker, three non-smokers).

Synovia from two patients with osteoarthritis (OA) were also studied. One synovium (male patient, age 66 years) was processed commercially (Origene, Rockville, Maryland, USA); the second synovium (female patient, age 72 years) was sourced from tissue stocks. Their smoking status is unknown.

Informed consent was obtained for the use of all patient tissue, with the study approved by the New Zealand Multi-Regional Ethics Committee. The use of peripheral blood (PB) from normal healthy donors and associated work involving $\mathrm{PB}$ leukocytes was approved by the University of Otago Ethics committee.

\section{Isolation, culture, and stimulation of PB monocytes and monocyte-derived dendritic cells (mo-DCs)}

Peripheral blood mononuclear cells were isolated from heparinized venous blood of healthy non-smoking human donors by Ficoll density centrifugation. $\mathrm{CD}^{+} \mathrm{T}$-cells, $\mathrm{CD} 20^{+} \mathrm{B}$-cells, and $\mathrm{CD} 14^{+}$monocytes were purified using appropriate antibody-coated magnetic MACS ${ }^{\circledR}$ microbeads and an AutoMacs separator (Miltenyi Biotec, Bergisch Gladbach, Germany) according to the manufacturer's 
Table 1 Patient demographics and clinical data

\begin{tabular}{|c|c|c|c|c|}
\hline & \multicolumn{2}{|c|}{ Synovia } & \multicolumn{2}{|c|}{ Nodules } \\
\hline & Smokers $\left(n=6^{*}\right)$ & Non-smokers $\left(n=11^{*}\right)$ & Smokers $(n=4)$ & Non-smokers $(n=14)$ \\
\hline Female, \% & 83 & 64 & 100 & 71 \\
\hline Age, years** & $58(37-79)$ & $55(35-74)$ & $47(44-50)$ & $61(48-77)$ \\
\hline Disease duration, years** & $11(2-30)$ & $18(3-30)$ & $19(13-30)$ & $19(2-44)$ \\
\hline Nodules, $\mathrm{n}$ & $5(83 \%)$ & $9(82 \%)$ & $4(100 \%)$ & $14(100 \%)$ \\
\hline Erosions, $\mathrm{n}$ & $6(100 \%)$ & $10(91 \%)$ & $4(100 \%)$ & $13(93 \%)$ \\
\hline RF positive, $n$ & $6(100 \%)$ & $10(91 \%)$ & $4(100 \%)$ & $13(93 \%)$ \\
\hline ACPA Positive ${ }^{\dagger}, \mathrm{n} /$ total ACPA Titer $^{\dagger \dagger}$ & $\begin{array}{c}5 / 5(100 \%) \\
157 \pm 45\end{array}$ & $\begin{array}{l}8 / 9(89 \%) \\
177 \pm 26\end{array}$ & $\begin{array}{c}4 / 4(100 \%) \\
193 \pm 57\end{array}$ & $\begin{array}{c}12 / 13(92 \%) \\
157 \pm 22\end{array}$ \\
\hline $\mathrm{ESR}^{* *}$ & $34(3-85)$ & $33(13-64)$ & $30(13-64)$ & $33(6-54)$ \\
\hline
\end{tabular}

* Three patients (one smoker, two non-smokers) provided two synovial samples. ${ }^{* *}$ mean values with the range in parenthesis. ${ }^{\dagger}$ For some patients, tissue samples pre-dated the availability of tests for anticitrullinated peptide antibody (ACPA); ${ }^{+\dagger}$ Mean values \pm SEM. Mean ACPA titers were not significantly different. $n$, number of patients; RF, rheumatoid factor; SEM, standard error of the mean,]; ESR, erythrocyte sedimentation rate.

instructions. Lymphocytes were used without further manipulation.

CD14 $4^{+}$monocytes were resuspended in RPMI 1640 medium supplemented with $10 \%$ fetal calf serum, $2 \mathrm{mM}$ glutamine, $50 \mathrm{U} / \mathrm{ml}$ penicillin, $50 \mu \mathrm{g} / \mathrm{ml}$ streptomycin (complete medium) and were stimulated with varied concentrations $(0.001 \mu \mathrm{M}$ to $10 \mu \mathrm{M})$ of benzo( $a$ )pyrene $(\mathrm{B} a \mathrm{P})$ or equivalent dimethyl sulfoxide (DMSO) alone (control) for $24 \mathrm{hr}$. Stimulation with $\mathrm{BaP}$, a polycyclic aromatic hydrocarbon present in cigarette smoke mimicked the effect of smoke. Alternatively, mononcytes were stimulated with $10 \mu \mathrm{M}$ phorbol 12-myristate 13-acetate (PMA) in complete medium for $72 \mathrm{hr}$ at $37^{\circ} \mathrm{C}$ and $5 \% \mathrm{CO}_{2}$.

Mo-DCs were generated from $\mathrm{CD} 14^{+}$monocytes by culture in complete medium with recombinant human granulocyte macrophage colony-stimulating factor (rhGMCSF), and rhIL-4 (each $25 \mathrm{ng} / \mathrm{ml}$; R\&D Systems, Minneapolis, Minnesota, USA) for 6 days at $37^{\circ} \mathrm{C}$ and $5 \% \mathrm{CO}_{2}$. Complete medium containing cytokines was replenished on day 3. Mo-DCs were further treated with either DMSO or $0.001 \mu \mathrm{M}$ to- $10 \mu \mathrm{M} \mathrm{BaP}$ in DMSO, or with polyinosinic:polycytidylic acid (Poly I:C) $(12.5 \mu \mathrm{g} /$ $\mathrm{ml}$ ) for $24 \mathrm{hr}$. Purity and maturation of DCs was assessed by staining with monoclonal antibodies to CD14, CD11c and CD83 (BD Biosciences, San Jose, California, USA) and FACS analysis. Immature mo-DCs were $\mathrm{CD} 14^{-}, \mathrm{CD} 11 \mathrm{c}^{+}, \mathrm{CD} 83^{\text {low }}$ and as expected became $\mathrm{CD} 14^{-}, \mathrm{CD} 11 \mathrm{c}^{+}, \mathrm{CD} 83^{\text {high }}$ upon maturation induced by Poly I:C stimulation.

\section{Quantitation by real-time polymerase chain reaction (RT-PCR)}

Total RNA was purified from rheumatoid nodule and synovial tissues or from cultured cells, and reverse transcribed using Superscript III (Invitrogen, Carlsbad, California, USA) as previously described [31]. Gene expression was assessed by RT-PCR using SYBR Green or TaqMan gene expression assays on an Applied Biosystems ABI 7300 sequence detection system. The SYBR Green primers (Invitrogen) were $A H R$ (sense): 5'-TTC AGT TCT TAG GCT CAG CGT -3', AHR (antisense): 5'-TGC TGC TCT ACA GTT ATC CTG G -3' and GAPDH (sense): 5'- TGC ACC ACC AAC TGC TTA GC -3', GAPDH (antisense): 5'GGC ATG GAC TGT GGT CAT GAG -3'. Commercially available Taqman assays (Applied Biosystems, Foster City, California, USA) were used to measure CYP1A1 (Hs00153120_m1), AHRR (Hs01005075_m1), IL17A (Hs00174383_m1), IL17F (Hs00369400_m1), IFNG (Hs00174143_m1), IL22 (Hs01574154_m1), IL23A (Hs00372324_m1), IL23R (Hs00332759_m1), FOXP3 (Hs00203958_m1), IL6 (Hs00985639_m1), IDO1 (Hs00984148_m1), TBX21 (Hs00203436_m1) and GAPDH (Hs99999905_m1) gene expression. All samples were assessed in triplicate. Samples were considered negative for gene expression when threshold cycle $(\mathrm{Ct})$ values were $<40$. Positive, test sample Ct values were extrapolated to standard curves obtained from human tonsil or lung standards, to calculate the mean amount of gene-specific RNA in each sample. Results are expressed as the mean \pm SEM ng RNA for each gene of interest, relative to the expression of glyceraldehede-3-phosphate dehydrogenase (GAPDH) RNA.

\section{Double immunofluorescence}

Seven- $\mu \mathrm{m}$ sections of frozen synovial tissues were cut and fixed in acetone for 10 minutess at $4^{\circ} \mathrm{C}$. After blocking with $5 \%$ goat immunoglobulins (IgGs; Sigma, Saint Louis, Missouri, USA) for 30 minutes at room temperature, the sections were incubated separately with cell-specific mouse monoclonal anti-CD3 (T cells; clone UCHT1), anti-CD20 (B cells; clone L26; DAKO, Glostrup, Denmark), anti-CD14 (monocytes/macrophages; clone FMC17), anti-DCs (clones CMRF44 [32] and CMRF56 [33,34]), anti-CD303(BDCA-2) (pDCs; clone AC144; Miltenyi Biotec), anti-CD1 (imDC; clone Na134), or anti-prolyl 4hydroxylase (fibroblast; clone 5B5; Abcam, Cambridge, UK) overnight at $4{ }^{\circ} \mathrm{C}$, followed by incubation with 
AlexaFluor568-conjugated goat anti-mouse antibody (diluted 1:1500; Invitrogen) for $1.5 \mathrm{hr}$ at $4^{\circ} \mathrm{C}$. The sections were then blocked with 5\% mouse IgGs for 30 minutes at room temperature following by incubation with biotinylated mAbs either against AHR (clone RPT9; Abcam) or CYP1A1 (clone b-2; Santa Cruz Biotechnology, Santa Cruz, California, USA) overnight, at $4^{\circ} \mathrm{C}$ with subsequent incubation with AlexaFluor488-conjugated streptavidin $(10 \mu \mathrm{g} / \mathrm{ml}$; Invitrogen) for 30 minutes, at RT. Cell nuclei were identified by counterstaining with Hoechst 33342 $(2.5 \mu \mathrm{g} / \mathrm{ml})$. Negative controls included the omission of primary antibodies and substitution of primary antibodies with mouse-named IgGs (DAKO). Co-localization of fluorescent staining was assessed by epifluorescence microscopy using a Zeiss microscope fitted with SpotRT digital camera and imaging software (Diagnostic Instruments, Sterling Heights, Michigan, USA). All samples were assessed by a single observer (MK) in a blinded fashion and verified by a second observer (PAH).

\section{Statistical analysis}

Differences in gene-expression levels were analyzed by the Mann-Whitney $U$-test. Where appropriate data was log transformed to stabilise the variance. The one-way analysis of variance (ANOVA) multirange post hoc Tukey's test was used when multiple comparisons were analyzed. Fisher's exact probability test was used to measure association. Correlation coefficients were determined by rank correlation using a nonparametric Spearman test. Analyses were done using Prism for Windows v4.03 (GraphPad Software Inc, San Diego, California, USA) or STATA11 statistical software. A probability level of $5 \%$ was considered significant for all statistical analysis.

\section{Results}

\section{Smoking contributes to AHR activation in inflamed synovial tissue}

AHR expression was present in both synovial tissues and nodules. Expression was higher in synovia (7.00 $\pm 1.12 \mathrm{ng}$ RNA, $\mathrm{n}=20)$ compared to nodules $(2.76 \pm 0.37 \mathrm{ng}$ RNA, $\mathrm{n}=18, P<0.0006$ ) (Figure $1 \mathrm{~A}$ ), but these levels of $A H R$ expression in inflamed rheumatoid tissues were not affected by smoking (Figure 1B).

Expression of the prototypic AHR responsive gene, $C Y P 1 A 1$ was used to establish the activation status of AHR in synovial and nodule tissues. CYP1A1 transcript was detected in $7 / 20$ synovial membranes $\left(35 \% \mathrm{CYP}^{\mathrm{A}} 1^{+}\right)$ and in $7 / 18$ nodules $\left(39 \% \mathrm{CYP} 1 \mathrm{~A} 1^{+}\right)$. We considered whether smoking was a factor influencing the activation of AHR, reflected by the CYP1A1 expression. We found six of the $7 \mathrm{CYP} 1 \mathrm{~A} 1^{+}$synovia were from smokers, whereas 12/13 CYP1A1 ${ }^{-}$synovia were from patients who were non-smokers. The association between patients who smoke and the activation of AHR was significant in inflamed synovium (Fisher's exact test, $P=0.005$ ) (Table 2) but was not evident in the separate cohort of 18 patients who provided nodule tissues (Table 2).

Levels of $C Y P 1 A 1$ expression were also significantly higher in synovial tissues from RA patients who smoked compared to non-smokers $(0.048 \pm 0.011$ vs. $0.003 \pm$ $0.003 \mathrm{ng}$ RNA respectively, $P=0.004)$. There was no such difference in nodule tissues $(0.21 \pm 0.12$ vs. $0.27 \pm$ 0.25 ng RNA, Figure 1C). Similarly, expression of the AHRR gene, which also depends on AHR activation and consequent transcription activity [35], was significantly higher in synovial tissues from RA patients who smoked when compared to non-smokers $(1.79 \pm 0.48$ vs. $0.53 \pm$ $0.21 \mathrm{ng}$ RNA, $P=0.036)$; this was not the case in nodule tissues $(4.82 \pm 3.41$ vs. $1.78 \pm 0.95$ ng RNA respectively, Figure 1D). There was a statistically significant positive correlation between $C Y P 1 A 1$ and $A H R R$ expression in synovial tissues (Spearman $\mathrm{r}=0.71, P=0.0005$ ) that also occurred in nodules (Spearman $r=0.62, P=0.0062$, data not shown).

Variable expression of $A H R$ was also observed in synovia from separate patients with OA. Expression levels overlapped with the range established for rheumatoid synovia (Figure 1E). Irrespective of the extent of $A H R$ expression, CYP1A1 expression was not detected in OA synovia.

Possible long-term effect of smoking on AHR expression and activation within synovial tissue was considered. Three patients providing four synovial samples were exsmokers, having ceased smoking $\geq 8$ years prior. Levels of synovial $A H R$ expression were equivalent between patients who were smokers $(n=7)$, ex-smokers $(n=4)$ and those who had never smoked $(\mathrm{n}=9)$, consistent with a lack of effect from smoking on $A H R$ expression (Additional file 1). CYP1A1 expression was not detectable in ex-smokers, suggesting no long-term effect from smoking on AHR activation (Additional file 1).

\section{Inflammatory genes that reflect the downstream influence of AHR-activation}

We further considered the implications of smoking for the expression of a number of immuno-inflammatory genes implicated in RA. Experimentally, Th17 cells are a direct cellular target of AHR agonists [26]. Their signature cytokine, IL-17A has been implicated in the pathogenesis of RA [36]. As such, Th17 cells provide a possible link between smoking, AHR activation and the exacerbation of synovial inflammation in RA. However, we found significantly less $I L 17 A$ gene expression in synovial tissue from smokers when compared to nonsmokers (Figure 2) and a negative association between $I L 17 A$ and $C Y P 1 A 1$ gene expression (Spearman $\mathrm{r}=$ -0.51, $P=0.022)$. 


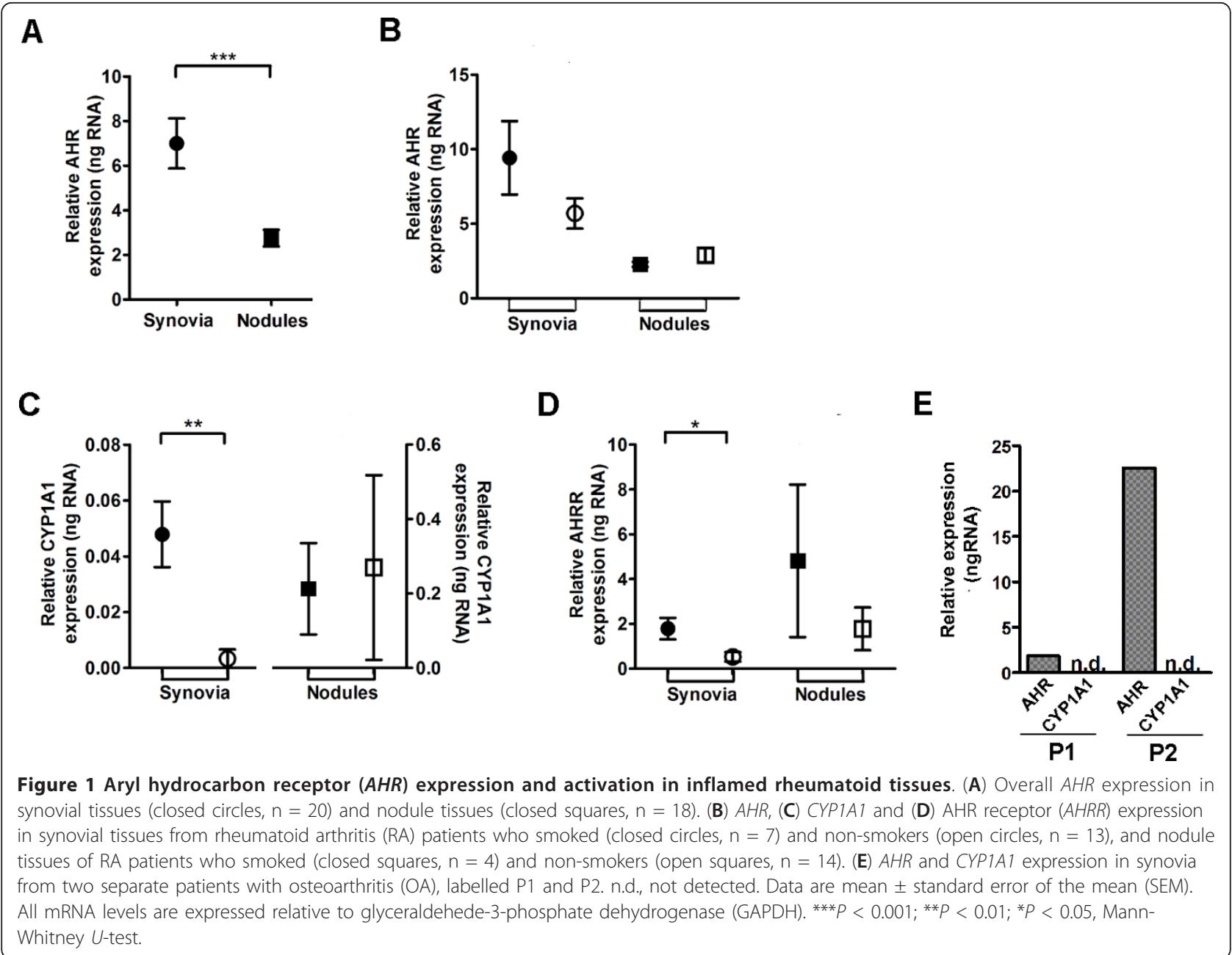

Amongst other Th17 cell cytokines, expression of the IL $17 F$ gene was not affected by smoking but was restricted to CYP1A1- synovia, whereas IL22 gene expression was not detected in any synovia (data not shown). We also considered the potential for smoking to impact upstream of IL17A but found no evidence of

Table 2 Patient smoking status and tissue aryl hydrocarbon receptor (AHR) activation

\begin{tabular}{|c|c|c|c|c|}
\hline \multicolumn{2}{|c|}{$\begin{array}{l}\text { Patient } \\
\text { Tissue contribution }\end{array}$} & \multicolumn{2}{|c|}{ Patient smoking status* } & \multirow[b]{2}{*}{$P$-value ${ }^{\ddagger}$} \\
\hline & & Smoker & Non-Smoker & \\
\hline \multirow[t]{3}{*}{ Synovia } & $\mathrm{CYP} 1 \mathrm{~A} 1^{+}$ & $6^{+}$ & 1 & \\
\hline & CYP1A1 ${ }^{-}$ & 1 & $12^{\dagger}$ & \\
\hline & & & & 0.005 \\
\hline \multirow[t]{3}{*}{ Nodules } & CYP1A1 ${ }^{+}$ & 2 & 4 & \\
\hline & CYP1A1 $1^{-}$ & 2 & 10 & \\
\hline & & & & 0.57 \\
\hline
\end{tabular}

*Patient smoking status when tissue sample was taken; ${ }^{\dagger}$ Patients contributing paired samples were considered once for statistical analysis; ${ }^{\ddagger} P$-value obtained by Fisher's exact probability two-tailed test an impact on gene expression of the critical cytokine IL23, nor of the IL23 receptor (IL23R). Similarly, smoking had no effect on Th1-cell mediated inflammation via interferon- $\gamma$ (IFNG), T-bet (TBX21) or FOXP3 gene expression in synovia (Figure 2 ).

Human DCs are implicated in the response of inflamed synovial tissue to smoking

Next we sought to identify the cell type(s) expressing AHR and showing AHR activation in inflamed synovial tissues. Using double immunofluorescence staining, CYP1A1 protein was observed only in CYP1A $1^{+}$synovia from RA patients who were smokers. In these synovia, both AHR and CYP1A1 proteins were produced by early differentiating CMRF44 $4^{+}$and CMRF56 $6^{+}$DCs (Figure 3A, $\mathrm{B}, \mathrm{C})$. These $\mathrm{AHR}^{+} / \mathrm{CYP} 1 \mathrm{~A} 1^{+} \mathrm{DCs}$ were mainly observed in close proximity to $\mathrm{T}$ and $\mathrm{B}$ cells (data not shown). Staining for AHR was cytoplasmic and in some DCs more obviously perinuclear, with small amounts of AHR protein localized within the nucleus, consistent with AHR activation (Figure 3B). Amongst the other cell types 


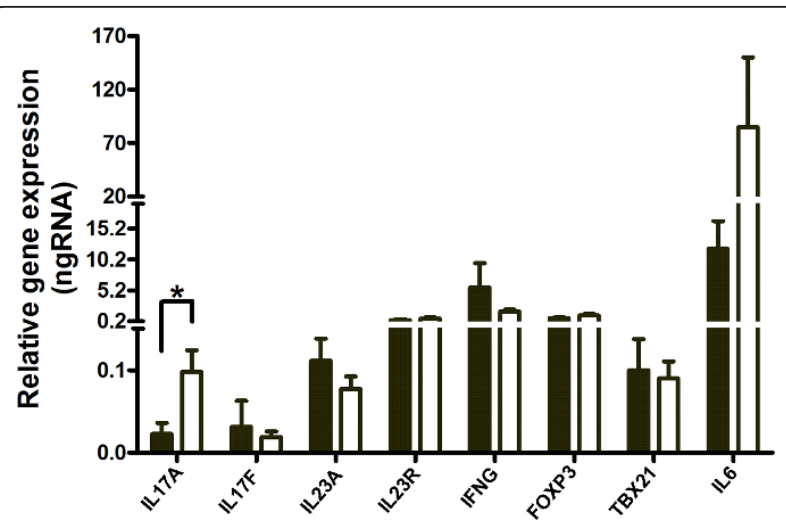

Figure 2 The effect of smoking on immune-inflammatory gene expression levels in rheumatoid arthritis (RA) synovia. The

figure shows mean gene expression levels \pm standard error of the mean (SEM) in synovia obtained from patients with RA who smoked (solid bars) compared to non-smokers (open bars). All mRNA levels are expressed relative to glyceraldehede-3-phosphate

dehydrogenase (GAPDH). ${ }^{*} P<0.05$, Mann Whitney U-test.

examined, rare (much less than $1 \%$ ) $\mathrm{CD}^{+} \mathrm{T}$ cells produced AHR and CYP1A1 proteins (Figure 3D, E). Although most $\mathrm{CD}_{303^{+}}$plasmacytoid DCs (pDCs) produced AHR protein, only occasional CD20 ${ }^{+} \mathrm{B}$ cells were $\mathrm{AHR}^{+}$and neither pDCs nor $\mathrm{B}$ cells produced detectable CYP1A1 protein. In synovium, immature $\mathrm{CD} 1^{+} \mathrm{DCs}$, CD $14^{+}$monocyte/macrophages and fibroblasts expressing prolyl-4-hydroxylase did not express either AHR or CYP1A1 protein (data not shown).

AHR or CYP1A1 protein was not detected in nodule lesions, regardless of smoking status (data not shown).

\section{Human mo-DCs are highly sensitive to AHR stimulation with $\mathrm{BaP}$}

Finally we questioned the type(s) of cells that respond to AHR ligands with evidence of AHR activation. We found comparable $A H R$ gene expression in $\mathrm{T}$ and $\mathrm{B}$ cells and monocytes from normal human PB cells and in mo-DCs (Figure 4A). Monocytes showed no significant change in $A H R$ or CYP1A1 expression when exposed to increasing concentrations of the AHR agonist, $\mathrm{B} a \mathrm{P}$ (Figure $4 \mathrm{~B}, \mathrm{C}$ ). In contrast, mo-DCs were extremely sensitive to $\mathrm{B} a \mathrm{P}$. The inducing effect of $\mathrm{B} a \mathrm{P}$ upon CYP1A1 expression in moDCs was evident at $0.1 \mu \mathrm{M}$ and maximal at $\mathrm{B} a \mathrm{P}$ concentrations of $1-10 \mu \mathrm{M}$ (Figure 4B, D), eliciting an average 30 -fold increase in CYP1A1 expression (Figure 4D). When compared to untreated cells we observed no effect on AHR or CYP1A1 expression in PMA-treated monocytes (Figure $4 \mathrm{C}$ ) or when mo-DC maturation was induced by PolyI:C (Figure 4D).

We sought evidence for a possible mechanism linking smoking, DC function and the effect on IL17A expression. Significant $I L 6$ gene expression was a feature of
mo-DCs induced to mature via PolyI:C stimulation (Figure 4E). This expression was inhibited by the AHR agonist, BaP (Figure 4E). Significant IDO1 expression was also a feature of PolyI:C-induced mo-DC maturation. However this expression was not affected by $\mathrm{B} a \mathrm{P}$ (Figure 4F).

\section{Discussion}

It is now well established that interactions between smoking and the SE increase the risk of developing RA [37] through effects mediated in the early pre-clinical stage of RA $[38,39]$. There are also indications that in established RA smoking is associated with more active disease and worse outcomes [20,21]. We hypothesized that in established RA, products within cigarette smoke, such as PAHs, may act upon the AHR, resulting in activation and downstream pro-inflammatory effects. In vitro work has suggested that this might include activation of Th17 cells, a pathway established as important to promotion of inflammation and joint damage in RA. We therefore sought evidence for AHR expression in RA lesions, the activation of AHR, and cells that showed evidence of AHR-mediated activation.

In advanced, erosive RA, we demonstrated $A H R$ expression in both synovial and subcutaneous nodule tissues. There was significantly more $A H R$ gene expression in synovial membrane but this expression was not affected by smoking. The nodule and synovium are different inflammatory lesions with respect to the composition of the cellular infiltrate. Subcutaneous nodules are granulomas, dominated by monocyte/macrophages but our data suggest that the difference in $A H R$ gene expression is not entirely due to this difference in inflammatory cell type. Limited analysis of synovia from patients with $\mathrm{OA}$ also indicated $A H R$ expression suggesting that inflammation, particularly associated with RA, is not entirely responsible for upregulated AHR expression.

Only in synovial tissue did we find evidence that smoking causes significant AHR activation, reported by increased expression of both the CYP1A1 and AHRR genes. Amongst patients who smoked, the majority showed this pattern of AHR-mediated activation. While was little evidence of AHR activation in synovium from non-smokers, there was also no indication that $A H R$ expression or activation in synovia from ex-smokers was different from patients who had never been smokers. Any evidence of AHR activation within synovial tissue was gone 8 to 33 years after ex-smokers ceased smoking, suggesting no lasting impact of smoking on AHRmediated mechanisms. Such a finding is at odds with the long-term effect of smoking on the risk of developing RA [8] and indicates that the activation of AHR by current smoking might be more important to ongoing synovial inflammation and thereby contribute to the severity of 


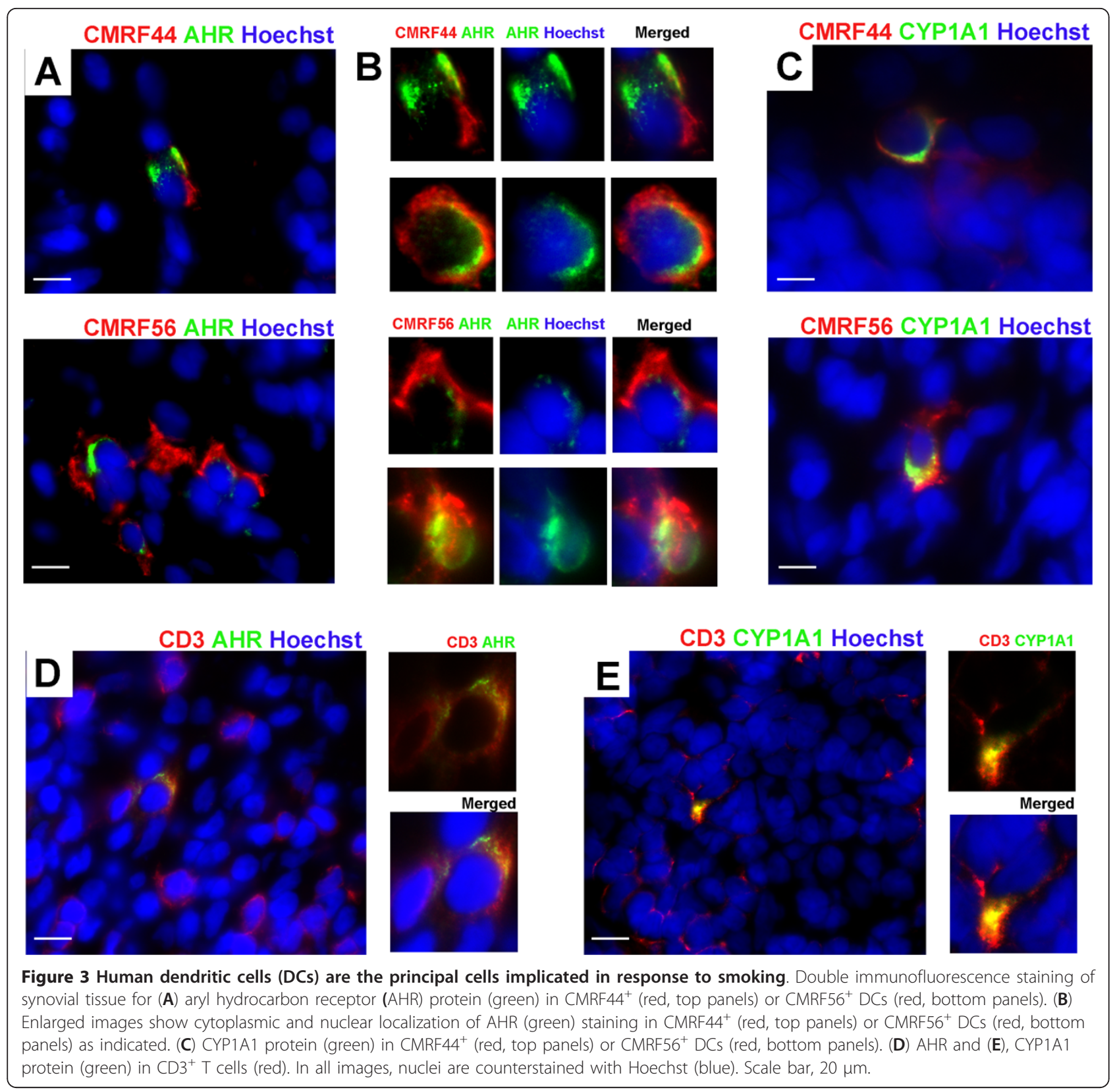

established RA. Consistent with this, a recent report also distinguishes an effect from current smoking, manifest as a reduced chance of response to methotrexate and to TNF inhibitor treatment. This compares with past smoking, which has no such influence on treatment [40]. Thus the risk of RA from smoking likely relates to a mechanism(s) independent of continued AHR activation.

The situation in nodules is more complex. In nodule tissues we found generally higher levels of $C Y P 1 A 1$ gene expression but were unable to demonstrate CYP1A1 protein. However, the most important observation was that CYP1A1 gene expression in nodules was independent of current smoking status or smoking history. This suggests an alternative (possibly endogenous) AHR ligand within these lesions, the nature of which remains to be determined. It suggests that the AHR-mediated response to cigarette smoke may be most pronounced in the inflamed synovium in patients with RA. Whether this is a unique aspect of RA remains to be established. Synovia from OA patients were CYP1A1-negative regardless of $A H R$ expression levels. Unfortunately, details of these patients' smoking status were unavailable.

While our data indicate smoking has a molecular impact within inflamed rheumatoid synovium, a critical question is how any AHR-mediated mechanism might influence the inflammatory process. We addressed this 


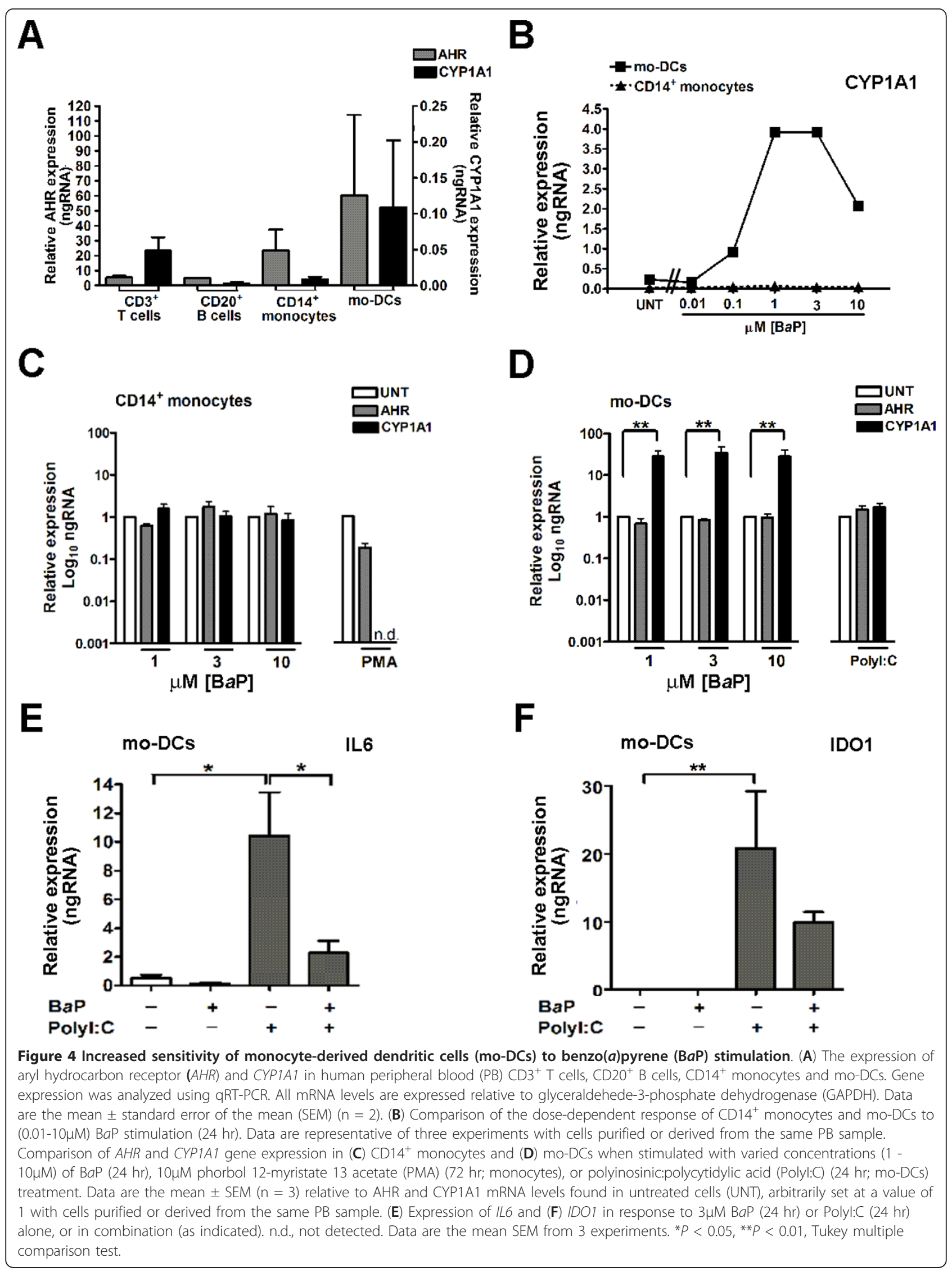


question by identifying the cell types within synovium that showed evidence of AHR activation. We found that a subset of CMRF $56^{+}$and/or CMRF $44^{+}$DCs within inflamed synovia were the predominant cells that expressed both AHR and CYP1A1 protein. There were also very occasional $\mathrm{T}$ cells and plasmacytoid DCs and, even more rarely, B cells in these synovia that expressed AHR protein. Amongst these non-DC types, only the $T$ cells showed evidence of AHR activation through CYP1A1 protein expression. In situ, these $\mathrm{T}$ cells were rare, even in synovia where generalized $\mathrm{T}$ cell infiltration was prominent. Synovial monocyte/macrophages were negative for both AHR and CYP1A1 protein. Clearly $\mathrm{AHR}^{+} / \mathrm{CYP} 1 \mathrm{~A} 1^{+} \mathrm{DCs}$ within the synovium display markers characteristic of early differentiating/activated DCs. The data highlight these cells as a potential focal point for the effects of cigarette smoke components within tissues and subsequent immune/inflammatory outcomes.

We considered further detail of mechanisms potentially utilized by DCs in response to AHR agonists. For this we used $\mathrm{B} a \mathrm{P}$, an AHR agonist that can be metabolized and is a known component of cigarette smoke [41]. When compared to paired PB CD14 $4^{+}$monocytes, mo-DCs responded to lower concentrations of $\mathrm{B} a \mathrm{P}$ in vitro, with AHR activation that culminated in significantly greater $C Y P 1 A 1$ expression at higher $\mathrm{B} a \mathrm{P}$ concentrations. Thus, $\mathrm{DCs}$ are more sensitive to $\mathrm{B} a \mathrm{P}$, an observation that is consistent with these being the most commonly observed cells showing evidence of AHR activation in the inflamed synovial tissue. Similarly, the insensitivity of monocytes to $\mathrm{B} a \mathrm{P}$ is consistent with the lower $A H R$ gene expression and activation, and lack of detectable protein observed in monocyte/ macrophage-dominated nodules. There are known immune/inflammatory consequences of DCs responding in such a sensitive manner to AHR agonists. In murine systems AHR activation can directly affect the differentiation and innate immune functions of inflammatory DCs without affecting their ability to interact with $\mathrm{T}$ cells $[42,43]$. Overall the studies in mice suggest AHR-mediated mechanisms influence the regulatory activities of DCs with consequences that skew naïve $\mathrm{T}$ cell differentiation towards Treg cells and away from Th17 cells. Such a response would be expected to limit immune/inflammatory activity $[44,45]$. We observed reduced expression of $I L 17 A$ in synovia from RA patients who smoked, a negative correlation between IL17A expression and AHR activation in synovia, and expression of IL17F that was limited to CYP1A1 ${ }^{-}$synovia. All are consistent with an effect of smoking on Th17 cell systems that involves AHR activation within intermediary DCs, rather than a direct effect on actual Th17 cells. As discussed, there was limited evidence of synovial $\mathrm{T}$ cells responding directly to smoking. There was no change in the presence of regulatory $\mathrm{T}$ cells (measured as FOXP3 expression), Th1 cells or Th1-like, ex-Th17 cells (TBX21/T-bet and IFNG expression) producing interferon- $\gamma$ [46] between synovia from smokers and non-smokers. While expression of the IL6 and IL23 genes was not significantly different between these synovia, the data were indicative of some effect on IL6 from current smoking. This possibility was strengthened by in vitro data showing that $\mathrm{B} a \mathrm{P}$ exposure inhibits IL6 expression by PolyI:C-stimulated mo-DCs. In this manner a critical regulatory signal, operative at the DC-T cell interface, could be affected by AHR activation in DCs, ultimately influencing DC control of T cells. Our data are consistent with this control negatively impacting on Th17 cells. We cannot exclude direct effects on $\mathrm{T}$ cells suggested by the rare $\mathrm{AHR}^{+} \mathrm{T}$ cells observed in synovia.

Such effects on potential or relevant pathogenic mechanisms contrast with epidemiological evidence showing increased risk of disease and worse inflammation in patients with RA who smoke. Interactions between smoking and the presence of $\mathrm{SE}^{+} H L A D R B 1$ alleles offer some explanation for this anomaly. All patients in our study were $\mathrm{SE}^{+}$thereby precluding detailed comparison of $\mathrm{SE}$ presence or copy number. Preliminary analysis, including this patient cohort, suggests an opposing effect of smoking and SE copy number on synovial IL17A expression.

In summary we have demonstrated the presence of the AHR receptor within synovial tissue from patients with $\mathrm{RA}$, with the potential to interact with polycyclic aromatic hydrocarbons in cigarette smoke. We have found evidence for activation via the AHR with increased levels of CYP1A1 and AHRR in synovial tissues from patients who continue to smoke. Based on in vitro data, we considered that such AHR activation, mediated by products in cigarette smoke, might activate Th17 cells. In contrast to this we found decreased expression of IL17, and that the predominant cell activated was the DC. Indications are that reduced IL6 expression by DCs is a possible consequence of cigarette smoke exposure, a factor that subsequently impacts negatively on ILI7A expression.

\section{Conclusions}

Our data suggests that cigarette smoke-induced changes in DC responses have the potential to be relevant to both the early pre-clinical phase of RA and the later stages of the disease. In the pre-clinical phase it is thought that antigenpresenting cells that express the shared epitope preferentially interact with post-translationally altered citrullinated antigens. Smoking is thought to act through promoting the citrullination of relevant antigens. Our data suggest that smoking might also act by altering DC responses. This effect on DCs could also be relevant to the influence of smoking on inflammation in established RA. Further detail of the effects of smoking on DC has the potential to 
provide further insights into mechanisms relevant to both the early induction phase of RA and worsening of established RA.

\section{Additional material}

Additional file 1: Long-term effect of smoking on aryl hydrocarbon receptor $(A H R)$ expression and activation in synovial tissues. Shown is any effect from current smoking or former smoking on AHR expression and CYPIA1 gene expression in joint synovial tissue from RA patients. Comparisons are made with data from non-smokers. There is no significant difference in synovial AHR expression between RA patients who are current smokers, ex-smokers or non-smokers. The expression of CYP1A1, reflecting AHR activation, is significantly different only in rheumatoid arthritis (RA) patients who continue to smoke.

\section{Abbreviations}

ACPA: anticitrullinated peptide antibody; AHR: aryl hydrocarbon receptor; AHRR: AHR repressor; BaP: benzo(a)pyrene; Ct: threshold cycle; CYP: cytochrome P450; DMARDs: disease-modifying anti-rheumatic drugs; DMSO: dimethylsulphoxide; GAPDH: glyceraldehede-3-phosphate dehydrogenase; L: interleukin; Mo-DC: monocyte-derived dendritic cell; OA: osteoarthritis; PAHs: polycyclic aromatic hydrocarbons; PB: peripheral blood; PMA: phorbol 12myristate 13 acetate; Poly I:C: polyinosinic:polycytidylic acid; RA: rheumatoid arthritis; RF: rheumatoid factor; rh: recombinant human; RT-PCR: real-time polymerase chain reaction; GMCSF: granulocyte, macrophage colony stimulating factor; SE: HLADRB1 shared eptiope; SEM: standard error of the mean; Th: T-helper; TNF: tumor necrosis factora; XRE: xenobiotic response element.

\section{Acknowledgements}

We thank Jody Hazlett for assistance with gene expression assays and Tony Merriman and Marilyn Merriman (Biochemistry, University of Otago) for providing patient DNA and for assistance in genotyping patients. We also thank Sarah Young and Michelle Wilson (Microbiology and Immunology, University of Otago) for assistance with dendritic cell isolation and Sheila Williams (Preventive and Social Medicine, University of Otago) for assistance with statistical analysis. This work was funded by Arthritis New Zealand and the Health Research Council of New Zealand.

\section{Author details}

'Department of Physiology, University of Otago, P.O. Box 913, Dunedin 9054, NZ. ${ }^{2}$ Department of Medicine, University of Otago, P.O. Box 913, Dunedin 9054, NZ. ${ }^{3}$ Department of Medicine, University of Otago, P.O. Box 4345, Christchurch 8041, NZ.

\section{Authors' contributions}

MK carried out the majority of the experimental work and statistical analysis, and drafted the manuscript. JH and LS coordinated patient recruitment, clinical assessment and sample recovery, participated in the design of the study, and helped draft the manuscript. PH conceived of the study, participated in its design and coordination, and helped draft the manuscript. All authors read and approved the final manuscript.

\section{Competing interests}

The authors declare that they have no competing interests.

Received: 27 April 2012 Revised: 7 September 2012 Accepted: 4 October 2012 Published: 4 October 2012

\section{References}

1. Masdottir B, Jónsson T, Manfredsdottir V, Víkingsson A, Brekkan A, Valdimarsson $\mathrm{H}$ : Smoking, rheumatoid factor isotypes and severity of rheumatoid arthritis. Rheumatol 2000, 39:1202-1205.

2. Manfredsdottir VF, Vikingsdottir T, Jonsson T, Geirsson AJ, Kjartansson O, Heimisdottir M, Siqurdardittir SL, Valdmansson H, Vikingsson A: The effects of tobacco smoking and rheumatoid factor seropositivity on disease aticity and joint damage in early rheumatoid arthritis. Rheumatol 2006, 45:734-740

3. Westhoff $G$, Rau R, Zink A: Rheumatoid arthritis patients who smoke have a higher need for DMARDs and feel worse, but they do not have more joint damage than non-smokers of the same serological group. Rheumatol 2008, 47:849-854.

4. Hyrich KL, Watson KD, Silman AJ, Symmons DP, British Society for Rheumatology Biologics Register: Predictors of response to anti-TNF alpha therapy among patients with rheumatoid arthritis: results from the British Society for Rheumatology Biologics Register. Rheumatol 2006, 45:1558-1565.

5. Abhishek A, Butt S, Gadsby K, Zhang W, Deighton CM: Anti-TNF alpha agents are less effective for the treatment of rheumatoid arthritis in current smokers. Journal of Clinical Rheumatology 2010, 16:15-18.

6. van der Woude D, Young A, Jayakumar K, Mertens BJ, Toes RE, van der Heijde D, Huizinga TW, van der Helm-van Mil AH: Prevalence of and predictive factors for sustained desease-modifying anti-rheumatic drug free remission in rheumatoid arthritis: results from two large early arthritis cohorts. Arthritis Rheum 2009, 60:2262-2271.

7. MacGregor AJ, Snieder H, Rigby AS, Koskenvuo M, Kaprio J, Aho K, Silman AJ: Characterizing the quantitative genetic contribution to rheumatoid arthritis using data from twins. Arthritis Rheum 2000, 43:30-37.

8. Scott DL, Wolfe F, Huizinga TW: Rheumatoid arthritis. Lancet 2010, 376:1094-1108.

9. Moreno I, Valenzuela A, Garcia A, Yelamos J, Sanchez B, Hernanz W: Association of the shared epitope with radiological severity of rheumatoid arthritis. J Rheumatol 1996, 23:6-9.

10. Valenzuela A, Gonzalez-Escribano MF, Rodriguez R, Moreno I, Garcia A, Nunez-Roldan A: Association of HLA shared epitope with joint damage progression in rheumatoid arthritis. Hum Immunol 1999, 60:250-254.

11. van der Helm-van Mil AH, Toes RE, Huizinga TW: Genetic variants in the prediction of rheumatoid arthritis. Ann Rheum Dis 2010, 69:1694-1696.

12. Plenge RM, Seielstad M, Padyukov L, Lee AT, Remmers EF, Ding B, Liew A, Khalili H, Chandrasekeran A, Davies LR, Li W, Tan Ak, Bonnard C, Ong RT, Thalamuthu A, Pettersson S, Liu C, Tian C, Chen WW, Carulli JP, Beckman EM, Altshuler D, Alfredsson L, Criswell LA, Amos Cl, Seldin MF, Kastner DL, Klareskog L, Gregersen PK: TRAF1-C5 as a risk locus for rheumatoid arthritis-a genomewide study. N Engl J Med 2007, 357:1199-1209.

13. Plenge RM, Padyukov L, Remmers EF, Purcell S, Lee AT, Karlson EW, Wolfe F, Kastner DL, Alfredsson L, Altshuler D, Gregersen PK, Klareskog L, Rioux JD: Replication of putative candidate-gene associations with rheumatoid arthritis in $>4,000$ samples from North America and Sweden: association of susceptibility with PTPN22, CTLA4, and PADI4. Am J Hum Genet 2005, 77:1044-1060.

14. Heliovaara M, Aho K, Aromaa A, Knekt P, Reunanen A: Smoking and risk of rheumatoid arthritis. J Rheumatol 1993, 20:1830-1835.

15. Finckh A, Dehler S, Costenbader KH, Gabay C: Cigarette smoking and radiographic progression in rheumatoid arthritis. Ann Rheum Dis 2007, 66:1066-1071.

16. Harrison BJ, Silman AJ, Wiles NJ, Scott DG, Symmons DP: The association of cigarette smoking with disease outcome in patients with early inflammatory polyarthritis. Arthritis Rheum 2001, 44:323-330.

17. Masdottir B, Jonsson T, Manfredsdottir V, Vikingsson A, Brekkan A, Valdimarsson $\mathrm{H}$ : Smoking, rheumatoid factor isotypes and severity of rheumatoid arthritis. Rheumatol 2000, 39:1202-1205.

18. Westhoff $G$, Rau R, Zink A: Rheumatoid arthritis patients who smoke have a higher need for DMARDs and feel worse, but they do not have more joint damage than non-smokers of the same serological group. Rheumatol 2008, 47:849-854.

19. Kitamura M, Kasai A: Cigarette smoke as a trigger for the dioxin receptormediated signaling pathway. Cancer Lett 2007, 252:184-194.

20. Makrygiannakis D, Hermansson M, Ulfgren A-K, Nicholas AP, Zendman AJ, Eklund A, Grunewald J, Skold CM, Klareskpg L, Catrina Al: Smoking increases peptigylarginine deiminase 2 enzyme expression in human lungs and increases cirullination in BAL cells. Ann Rheum Dis 2008, 67:1488-1492.

21. Mahdi H, Fisher BA, Kallberg H, Plant D, Malmstrom V, Ronnelid J, Charles P, Ding B, Alfredsson L, Padyukov L, Symmons DP, Venables PJ, Klareskog L, Lundberg K: Specific interaction between geneotype, smoking and 
autoimmuity to citrullinated alpha-enolase in the etiology of rheumatoid arthritis. Nat Genet 2009, 41:1319-1324.

22. Wegner N, Lundberg K, Kinloch A, Fisher B, Malmstom V, Feldmann M, Venables PJ: Autoimmunity to specific citrullinated proteins gives the first clues to the etiology of rheumatoid arthritis. Immunol Rev 2010 233:34-54.

23. Montes A, Dieguez-Gonzalez R, Perez-Pampin E, Calaza M, Mera-Varela A Gomez-Reino JJ, Gonzalez A: Particular association of clinical and genetic features with autoimunity to citrullinated a-enolase in rheumatoid arthritis. Arthritis Rheum 2011, 63:654-661.

24. von Delwig A, Locke J, Robinson JH, Ng WF: Response of Th17 cells to citrullinated arthritogenic aggrecan peptide in patients with rheumatoid arthritis. Arthritis Rheum 2010, 62:143-149.

25. Klareskog L, Ronnelid J, Lundberg K, Papyukov L, Alfredsson L: Immunity to citrullinated proteins in rheumatoid arthritis. Ann Rev Immunol 2008, 26:651-675.

26. Veldhoen M, Hirota K, Westendorf AM, Buer J, Dumoutier L, Renauld JC, Stockinger B: The aryl hydrocarbon receptor links TH17-cell-mediated autoimmunity to environmental toxins. Nature 2008, 453:106-109.

27. Moran EM, Mullan R, McCormick J, Connolly M, Sullivan O, Fitzgerald O, Bresnihan B, Veale DJ, Fearon U: Human rheumatoid arthritis tissue production of IL-17A drives matrix and cartilage degradation: synergy with tumour necrosis factor-alpha, Oncostatin $\mathrm{M}$ and response to biologic therapies. Arthritis Res Ther 2009, 11:R113.

28. Adamopoulos IE, Chao CC, Geissler R, Laface D, Blumenschein W, Iwakura Y, McClanahan T, Bowman EP: Interleukin-17A upregulates receptor activator of NF-kappaB on osteoclast precursors. Arthritis Res Ther 2010, 12:R29.

29. Lubberts E: IL-17/Th17 targeting: on the road to prevent chronic destructive arthritis? Cytokine 2008, 41:84-91.

30. Arnett FC, Edworthy SM, Bloch DA, MCShane DJ, Fries JF, Cooper NS, Healey LA, Kaplan SR, Liang MH, Luthra HS, Medsger TA, Mitchell DM, Neustadt DH, Pinals RS, Schaller JG, Sharp JT, Wilder RL, Hunder GG: The American Rheumatism Association 1987 revised criteria for the classification of rheumatoid arthritis. Arthritis Rheum 1988, 31:315-324.

31. Stamp LK, Easson A, Pettersson L, Highton J, Hessian PA: Monocyte derived interleukin (IL)-23 is an important determinant of synovial IL-17A expression in rheumatoid arthritis. J Rheumatol 2009, 36:2403-2408.

32. Hock BD, Starling GC, Daniel PB, Hart DN: Characterization of CMRF-44, a novel monoclonal antibody to an activation antigen expressed by the allostimulatory cells within peripheral blood, including dendritic cells. Immunology 1994, 83:573-581.

33. Coventry BJ, Lee PL, Gibbs D, Hart DN: Dendritic cell density and activation status in human breast cancer - CD1a, CMRF-44, CMRF-56 and CD-83 expression. Br J Cancer 2002, 86:546-551.

34. Hock BD, Fearnley DB, Boyce A, McLellan AD, Sorg RV, Summers KL, Hart DN: Human dendritic cells express a 95 kDa activation/ differentiation antigen defined by CMRF-56. Tissue Antigens 1999, 53:320-334.

35. Brauze D, Widerak M, Cwykiel J, Szyfter K, Baer-Dubowska W: The effect of aryl hydrocarbon receptor ligands on the expression of AhR, AhRR, ARNT, Hif1alpha, CYP1A1 and NQO1 genes in rat liver. Toxicol Lett 2006, 167:212-220.

36. Kirkham BW, Lassere MN, Edmonds JP, Juhasz KM, Bird PA, Lee CS, Shnier R Portek IJ: Synovial membrane cytokine expression is predictive of joint damage progression in rheumatoid arthritis: a two-year prospective study (the DAMAGE study cohort). Arthritis Rheum 2006, 54:1122-1131.

37. Kallberg $H$, Padyukov L, Plenge RM, Ronnelid J, Gregersen PK, van der Helm-van Mil AH, Toes RE, Hulzinga TW, Klareskog L, Alfredsson L: Genegene and gene-environment interactions involving HLA-DRB1, PTPN22, and smoking in two subsets of rheumatoid arthritis. Am J Hum Genet 2007, 80:867-875.

38. Klareskog L, Gregersen PK, Huizinga TW: Prevention of autoimmune rheumatic disease: state of the art and future perspectives. Ann Rheum Dis 2010, 69:2062-2066.

39. Kokkonen H, Soderstrom I, Rocklov J, Hallmans G, Lejon K, Rantapaa Dahlqvist S: Up-regulation of cytokines and chemokines predates the onset of rheumatoid arthritis. Arthritis Rheum 2010, 62:383-391.

40. Saevarsdottir S, Wedren S, Seddighzadeh M, Bengtsson C, Wesley A, Lindblad S, Askling J, Alfredsson L, Klareskog L: Patients with early rheumatoid arthritis who smoke are less likely to respond to treatment with methotrexate and tumor necrosis factor inhibitors: observations from the Epidemiological Investigation of Rheumatoid Arthritis and the Swedish Rheumatology Register cohorts. Arthritis Rheum 2011, 63:26-36.

41. Nguyen $L P$, Bradfield CA: The search for endogenous activators of the aryl hydrocarbon receptor. Chem Res Toxicol 2008, 21:102-116.

42. Simones T, Shepherd DM: Consequences of AhR activation in steadystate dendritic cells. Toxicol Sci 2010, 119:293-307.

43. Bankoti J, Rase B, Simones T, Shepherd DM: Functional and phenotypic effects of AhR activation in inflammatory dendritic cells. Toxicol Appl Pharmacol 2010, 246:18-28.

44. Nguyen NT, Kimura A, Nakahama T, Chinen I, Masuda K, Nohara K, FujiiKuriyama Y, Kishimoto T: Aryl hydrocarbon receptor negatively regulates dendritic cell immunogenicity via a kynurenine-dependent mechanism. Proc Natl Acad Sci USA 2010, 107:19961-19966.

45. Mezrich JD, Fechner JH, Zhang X, Johnson BP, Burlingham WJ, Bradfield CA: An interaction between kynurenine and the aryl hydrocarbon receptor can generate regulatory T cells. J Immunol 2010, 185:3190-3198.

46. Hirota K, Duarte JH, Veldhoen M, Hornsby E, Li Y, Cua DJ, Ahlfors H, Wihelm C, Tolaini M, Menzel U, Garefalaki A, Potocnik AJ, Stockinger B: Fate mapping of IL-17 producing $T$ cells in inflammatory responses. Nat Immunol 2011, 12:255-263.

doi:10.1186/ar4046

Cite this article as: Kazantseva et al:: Dendritic cells provide a potential link between smoking and inflammation in rheumatoid arthritis. Arthritis Research \& Therapy 2012 14:R208.

\section{Submit your next manuscript to BioMed Central and take full advantage of:}

- Convenient online submission

- Thorough peer review

- No space constraints or color figure charges

- Immediate publication on acceptance

- Inclusion in PubMed, CAS, Scopus and Google Scholar

- Research which is freely available for redistribution

Submit your manuscript at www.biomedcentral.com/submit
Ciomed Central 